\title{
KEARIFAN LOKAL MENUJU SDGs'14: STUDI KASUS LUBUK LARANGAN TEPIAN NAPAL KABUPATEN BUNGO PROVINSI JAMBI
}

\section{Local Wisdom to SDGs'14: Case Study of Lubuk Larangan Tepian Napal, Bungo Regency, Jambi Province}

\author{
Oleh: \\ Muhammad Natsir Kholis ${ }^{1 *}$, Edwarsyah ${ }^{2}$ \\ ${ }^{1}$ Fakultas Perikanan Universitas Muara Bungo, Jl. Pangeran \\ Diponegoro, Cadika, Rimbo Tengah, Kabupaten Bungo, \\ Jambi 37211-Indonesia \\ ${ }^{2}$ Fakultas Perikanan dan Ilmu Kelautan Universitas Teuku \\ Umar, Jl. Alue Peunyareng, Ujong Tanoh Darat, Meureubo, \\ Kabupaten Aceh Barat, Aceh 23681-Indonesia \\ ${ }^{*}$ Korespondensi penulis: kholis2336@gmail.com
}

\begin{abstract}
ABSTRAK
Pergeseran kualitas habitat, pencemaran dan masuknya beberapa spesies asing menyebabkan perubahan lingkungan ekologis perairan sungai. Penelitian ini bertujuan untuk menganalisis sistem kearifan lokal menuju SDGs'14, studi kasus kearifan lokal lubuk larangan tepian napal Sungai Batang Tebo Kabupaten Bungo Provinsi Jambi. Penelitian dilaksanakan pada Bulan Juli-Agustus 2019 dengan metode survei. Analisis data yang digunakan yaitu deskriptif kuantitatif dengan teknik flag modelling Ecosystem Approach Fisheries Management(EAFM) yang dimodifikasi. Hasil penelitian menunjukkan bahwa kearifan lokal lubuk larangan tepian napal sudah mengarah ke SDGs'14 dengan kategori baik (light green flag). Sistem partisipatif, adat-istiadat dan kekeluargaan menjadi ciri khas kearifan lokal lubuk larangan dalam menjaga sumberdaya perikanan di Kabupaten Bungo Provinsi Jambi.
\end{abstract}

Kata kunci: EAFM, Muara Bungo, SDGs'14, sungai, Tanah Tumbuh

\begin{abstract}
Shifts in habitat quality, pollution and the entry of several foreign species cause changes in the ecological environment of river waters. The purpose of this research is to analyze the local wisdom system towards SDGs '14, a case study of local wisdom lubuk larangan tepian napal Batang Tebo river Bungo Regency Jambi Province. The study was conducted in July to August 2019 using survey methods. Analysis of the data used is quantitative descriptive with modified flag modeling Ecosystem Approach Fisheries Management (EAFM) techniques. The results showed that the local wisdom lubuk larangan tepian napal has led to SDGs'14 with the good category (light green flag). Participatory, customary and family systems are characteristic of local wisdom lubuk larangan in maintaining fisheries resources in Bungo Regency, Jambi Province.
\end{abstract}

Key words: EAFM, Muara Bungo, SDGs'14, river, Tanah Tumbuh

\section{PENDAHULUAN}

Pengelolaan sumberdaya perikanan saat ini dihadapkan beberapa permasalahan serius akibat adanya pemanfaatan berlebih (over exploitation), masih adanya pengoperasian alat tangkap yang merusak lingkungan (destructive fishing gears), terjadinya restorasi dan pergeseran kualitas habitat, pencemaran, masuknya atau adanya dominasi spesies asing (native species), pergeseran iklim global 
(climate change), bencana alam dan restorasi kawasan lindung menjadi kawasan ekonomi lainnya (Rengi dan Brown 2013); (Kholis et al. 2018). Permasalahan di lingkungan perairan sungai juga telah banyak terjadi, terutama di wilayah Kabupaten Bungo, Jambi dengan adanya kegiatan penambangan emas tanpa izin (PETI) menyebabkan lingkungan perairan sungai keruh dan bisa terindikasi tercemar. Selain itu PETI juga mampu menimbulkan konflik horizontal sesama masyarakat.

Sebagai wujud mengatasi permasalahan pengelolaan sumberdaya perikanan maka Perserikatan Bangsa-Bangsa (PBB) saat ini telah mengesahkan dokumen SDGs (Sustainable Development Goals) yang terdiri dari tujuh belas tujuan penting yang ingin dicapai pada tahun 2030. Konsep SDGs membahas mengenai pembangunan berkelanjutan yang global, dan bisa menjaga tiga dimensi penyeimbang antara lingkungan, sosial dan ekonomi (Ishartono dan Raharjo 2016).

Salah satu tujuan penting dalam pengelolaan sumberdaya perikanan yaitu point ke-14 tentang kehidupan bawah laut (life below water). Point ke-14 atau dikenal SDGs'14 memaknai bagaimana kita dapat melestarikan laut dan menjaga kehidupan sumberdaya laut untuk pembangunan yang berkelanjutan. Tetapi selain perairan laut, tidak salahnya kita melihat unsur penunjang kelestarian perairan laut yaitu perairan umum dan daratan. Bentuk penerapan SDGs'14 di perairan umum dan daratan dapat mencontoh beberapa kearifan lokal yang masih digunakan oleh sebagian masyarakat desa di Indonesia, seperti: panglima laot (Aceh); lubuk larangan (Jambi dan Sumatera Barat); lelang lebak lebung (Sumsel); ma'uwo, rantau larangan, dan upacara semah terubuk (Riau); kearifan lokal dedi-dedi (Cirebon), upacara adat labuh saji/hari nelayan (Sukabumi) dan kearifan lokal lainnya.

Kearifan lokal dapat diartikan sebuah nilai kebudayaan yang tidak bisa dipisahkan dari kehidupan masyarakat di Indonesia dan telah dilegalkan keeksistensiannya oleh konstitusional (hukum) negara (Oktaviani et al. 2016). Masyarakat pedalaman pada umumnya sangat mengenali lingkungannya sehingga mereka menerapkan budaya dalam memanfaatkan dan mengelola sumberdaya alam yang biasa disebut dengan kearifan lokal (Indrawan et al. 2007). Menurut Keraf (2002) kearifan lokal merupakan wujud keyakinan, kepemahaman atau wawasan, adat istiadat, pengetahuan serta etika yang menuntun tingkah laku manusia dalam kehidupan berkelompok secara ekologis. Perilaku ekologis masyarakat didukung oleh beberapa hal yaitu pola kepemimpinan, kondisi geografis, mata pencaharian masyarakat dan hukum adat, (Kurniasari et al. 2013). Dengan adanya strategi atau pengelolaan ke arah SDGs'14 di perairan sungai diharapkan permasalahan seperti PETI, illegal fishing, pencemaran perairan, dan konflik wilayah dapat teratasi, jika penerapan SDGs'14 dapat berjalan dengan baik. Tujuan penelitian ini adalah menganalisis sistem kearifan lokal lubuk larangan menuju SDGs'14, studi kasus kearifan lokal lubuk larangan tepian napal Sungai Batang Tebo Kabupaten Bungo Provinsi Jambi.

\section{METODE PENELITIAN}

Penelitian dilaksanakan pada Bulan Juli-Agustus 2019. Penelitian terkonsentrasi di lubuk larangan tepian napal Sungai Batang Tebo Kecamatan Tanah Tumbuh (Gambar 1). Metode yang dipilih pada penelitian ini yaitu metode survei, dengan teknik pengambilan data secara observasi dan pengamatan (visual) ke lapangan serta melakukan wawancara secara langsung kepada masyarakat. Sumber data utama yaitu data primer berupa data lingkungan: kondisi perairan, biologis (hasil tangkapan dan keanekaragaman) dan ekologi; data sosial: kegiatan illegal fishing, kegiatan sosial masyarakat dan tata kelembagaan; data ekonomi: finansial masyarakat. Sedangkan data sekunder sebagai data tambahan seperti: referensi dari jurnal ilmiah, buku bacaan dan laporan bulanan atau tahunan Desa dan Kecamatan.

Data hasil pengamatan dan wawancara dianalisis secara deskriptif kuantitatif mengacu kajian indikator Sustainable Development Goals (SDGs) Badan Pusat Statistik (2014), penjelasannya dilihat secara aktual dan sistematis dengan visualisasi penilaian domain (Tabel 1) menggunakan teknik flag modelling. Dalam pembuatan flag modelling menggunakan model bendera penghampiran ecosystem 
approach fisheries management/EAFM (Tabel 2) (Munandar et al. 2016; Edwarsyah et al. 2018) yang dimodifikasi sesuai kebutuhan analisis. Tahapan penilaian yaitu sebagai berikut (Adrianto et al. 2005):

1. Menentukan kriteria pada setiap komposit masing-masing domain SDGs'14 (kesehatan perairan, proporsi hasil tangkapan, illegal fishing, eutrofikasi dan tata kelola/kelembagaan)

2. Mengkaji keragaan masing-masing komposit yang diuji (kondisi perairan dan keanekaragaman hayati; jumlah hasil tangkapan; penggunaan alat penangkapan ikan yang merusak dan pelanggaran lainnya; aktivitas manusia; dan Peraturan Daerah (PERDA) dan Peraturan Dusun (PERDUS).

3. Masukan skor nilai atribut untuk setiap keragaan komposit pada indikator/kriteria (skor Likert berbasis ordinal $1,2,3$ )

4. Tentukan bobot untuk setiap komposit

5. Indeks domain dikembangkan masing-masing nilai atribut untuk setiap komposit dengan model fungsi :

$$
C_{a t}=S_{a i} \times W_{i}
$$

6. Indeks domain dikembangkan juga untuk seluruh performa SDG'14 pada setiap domain dengan model fungsi sebagai berikut:

$$
C-\text { domain }_{i}=\bar{X} C_{a t}-i
$$

domain ke-1, 2, 3 ...i

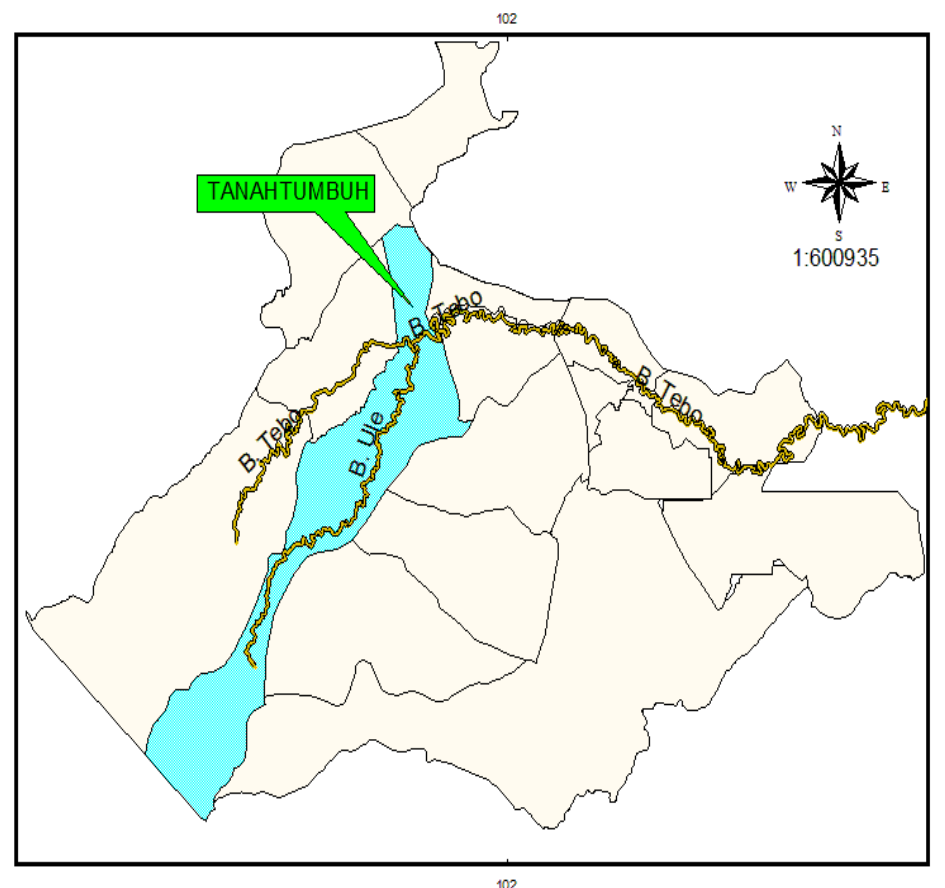

Peta Kecamatan Kabupaten Bungo

By: Muhammad Natsir Kholis Universitas Muara Bungo

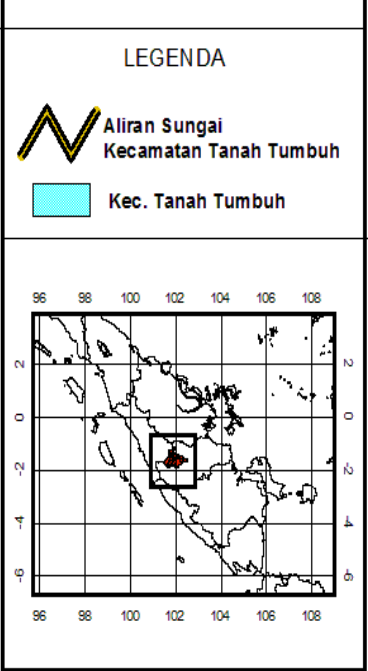

Gambar 1 Lokasi penelitian 
Tabel 1 Penilaian domain SDGs'14 untuk kearifan lokal lubuk larangan

\begin{tabular}{|c|c|c|c|c|}
\hline No & Domain & Komposit & Kriteria/Indikator & Bobot \\
\hline 1 & $\begin{array}{l}\text { Kesehatan } \\
\text { Perairan }\end{array}$ & $\begin{array}{l}\text { Kondisi perairan } \\
\text { dan } \\
\text { keanekaragaman } \\
\text { hayati }\end{array}$ & $\begin{array}{l}\text { 1=perairan tercemar } \& \\
\text { biodiversity rendah }\left(H^{\prime}<3,2\right. \\
\left.\text { atau } H^{\prime}<1\right) \text {, total spesies }<3 \text {; } \\
\text { 2=perairan tercemar sedang } \\
\text { biodiversity sedang } \\
\left(3,20<H^{\prime}<9,97 \text { atau } 1<H^{\prime}<3\right), \\
\text { jumlah spesies } 3-5 ; \\
\text { 3=tidak tercemar biodiversity } \\
\text { tinggi }\left(H^{\prime}>9,97 \text { atau } H^{\prime}>3\right), \\
\text { jumlah spesies }>5\end{array}$ & 20 \\
\hline 2 & $\begin{array}{l}\text { Proporsi Hasil } \\
\text { Tangkapan }\end{array}$ & $\begin{array}{l}\text { Jumlah hasil } \\
\text { tangkapan }\end{array}$ & $\begin{array}{l}\text { - } 1=\text { menurun ekstrim (rerata } \\
\text { turun }>25 \% \text { per tahun); } \\
\text { - } 2=\text { menurun minim (rerata turun } \\
<25 \% \text { per tahun); } \\
\text { - } 3=\text { stabil atau meningkat }\end{array}$ & 20 \\
\hline 3 & Illegal fishing & $\begin{array}{l}\text { Penggunaan alat } \\
\text { penangkapan } \\
\text { ikan yang } \\
\text { merusak dan } \\
\text { pelanggaran } \\
\text { lainnya }\end{array}$ & $\begin{array}{l}\text { - } 1 \text { =kemunculan pelanggaran }>10 \\
\text { kasus per tahun; } \\
\text { - } 2=\text { kemunculan pelanggaran } 5- \\
10 \text { kasus per tahun; } \\
\text { - } 3=\text { kemunculan pelanggaran }<5 \\
\text { kasus } \\
\text { per tahun }\end{array}$ & 20 \\
\hline 4 & Eutrofikasi & $\begin{array}{l}\text { Aktivitas } \\
\text { manusia }\end{array}$ & $\begin{array}{l}\text { - } 1 \text { = open access; } \\
\text { 2= masih ada aktivitas } \\
\text { menangkap ikan, PETI, mandi, } \\
\text { cuci dan kakus (MCK); } \\
\text { - } 3=\text { perairan tertutup dan } \\
\text { terlindungi }\end{array}$ & 20 \\
\hline 5 & $\begin{array}{l}\text { Tata kelola } \\
\text { (kelembagaan) }\end{array}$ & $\begin{array}{l}\text { Peraturan } \\
\text { Daerah } \\
\text { (PERDA) dan } \\
\text { Peraturan Dusun } \\
\text { (PERDUS) }\end{array}$ & $\begin{array}{l}\text { - } 1 \text { =tidak ada aturan tertulis } \\
\text { - } 2 \text { =adanya aturan tertulis tetapi } \\
\text { tidak dijalankan secara maksimal } \\
\text { - } 3=\text { =adanya aturan tertulis dan } \\
\text { dijalankan dengan baik }\end{array}$ & 20 \\
\hline \multicolumn{4}{|c|}{ Total } & 100 \\
\hline
\end{tabular}

Tabel 2 Visualisasi model bendera untuk penilaian SDGs'14

\begin{tabular}{ccc}
\hline Nilai Skor Domain & Model Bendera & Deskripsi \\
\hline $5-20$ & & Buruk \\
$21-35$ & Kurang Baik \\
$36-45$ & Sedang \\
$46-55$ & Baik \\
$56-65$ & Baik Sekali \\
\hline
\end{tabular}




\section{HASIL DAN PEMBAHASAN}

\section{Kearifan Lokal Lubuk Larangan}

Lubuk larangan yaitu suatu kawasan perairan umum dan daratan yang tidak diperbolehkan bagi siapapun untuk mengambil ikan dan/atau sumberdaya hayati lainnya kecuali sesudah diputuskan dalam musyawarah dusun atau telah dituangkan dalam peraturan dusun. Lokasi ini menjadi area yang mendukung untuk proliferasi (berkembang biak) ikan karena aman dan terlindungi (Yuliati dan Priyatna 2014; Dani et al. 2016). Secara lugas lubuk larangan adalah suatu area tertentu di perairan lotik (mengalir) yang dilindungi, dapat diartikan juga area tertutup bagi aktivitas manusia dalam rentang waktu tertentu (Handayani et al. 2018; Kholis et al. 2020). Sistem pengelolaan lubuk larangan dapat berbeda-beda, seperti sistem pengelolaan lubuk larangan di tepian napal dapat dilihat pada (Gambar 2).

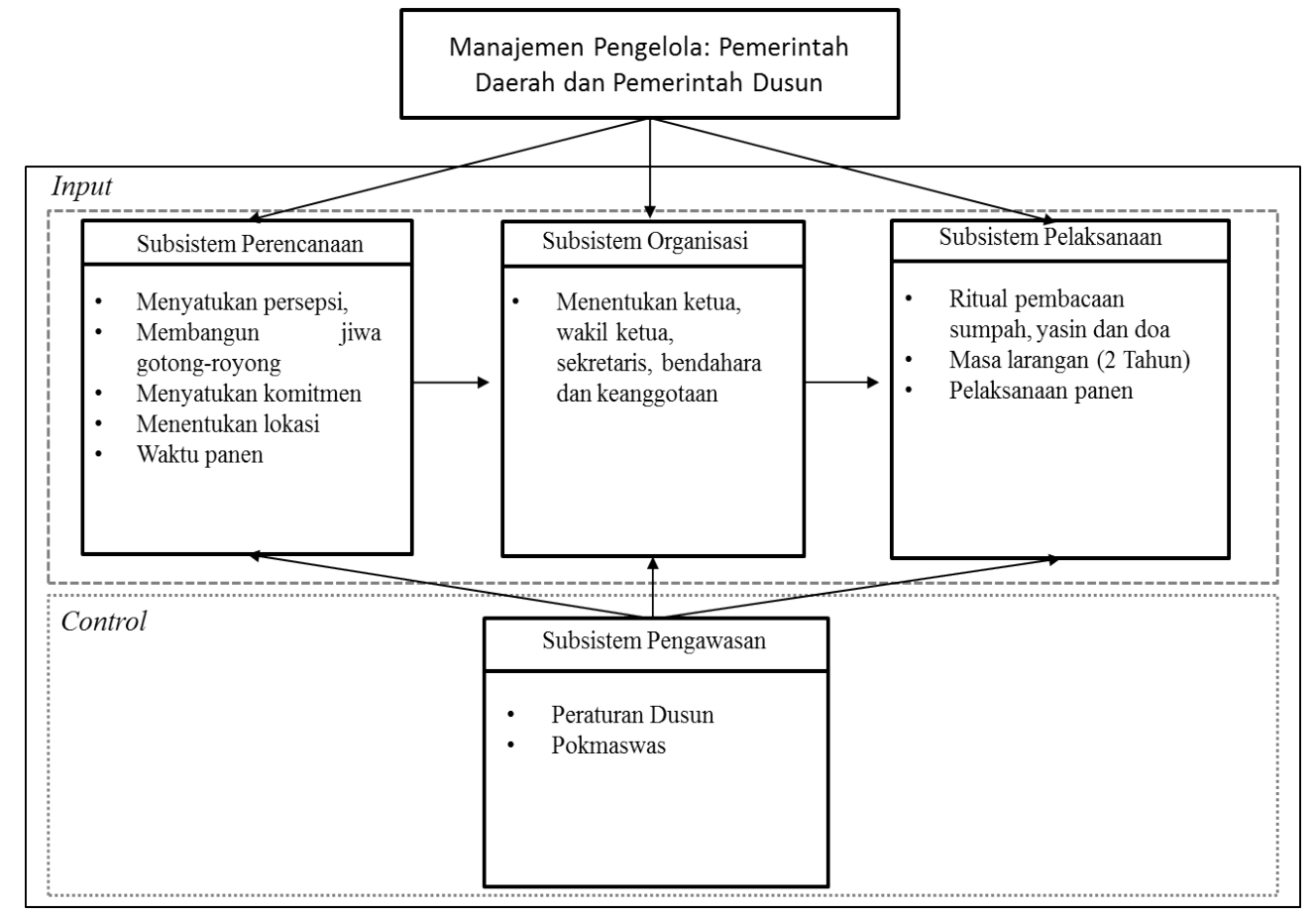

Gambar 2 Sistem pengelolaan lubuk larangan tepian napal

Gambar 2 menunjukkan bahwa pembentukan lubuk larangan tepian napal diawali beberapa tahapan/proses yaitu perencanaan (manyatukan persepsi, membangun jiwa gotong-royong, menyatukan komitmen, menentukan lokasi dan waktu panen); kemudian pengorganisasian (menentukan ketua, wakil ketua, sekretaris, bendahara dan keanggotaan); tahap pelaksanaan (ritual pembacaan sumpah, yassin, doa, masa larangan dua tahun dan pelaksanaan panen); tahap terakhir yaitu pengawasan (peraturan dusun dan POKMASWAS). Sistem pembagian/ pengelolaan hasil panen lubuk larangan yaitu 1) dialokasikan untuk pembangunan dusun, pembinaan kegiatan masyarakat dusun, dan prioritas lain sesuai musyawarah dusun; 2) jumlah hasil pendapatan dialokasikan juga untuk honorium dan biaya operasional POKMASWAS sebesar 15\%; 3) dana yang tersisa akan dikembalikan atau diserahkan ke pemerintah dusun.

Sumberdaya perikanan lubuk larangan atau suaka perikanan (reservat) memiliki sistem zonasi dalam mengelola sumberdaya perikanan yaitu:

1. Zona inti yaitu: (kawasan di mana ikan-ikan tersebut sama sekali tidak boleh di tangkap sepanjang tahun, zona ini dilindungi secara tetap, dalam area zona ini tidak boleh ada penangkapan ikan dan termasuk tidak boleh ada kegiatan lain yang dapat mencemari atau merusak habitat dan 
ekosistemnya. Karena fungsi dari zona inti ini adalah tempat ikan memijah, tempat ikan membesarkan anak-anaknya, tempat ikan berlindung dan mencari makan.

2. Zona Perikanan Berkelanjutan yaitu: (kawasan di mana ikan-ikan tersebut dilarang menangkap pada kurun waktu tertentu yang telah disepakati bersama, kawasan ini dapat dipanen sesuai dengan kesepakatan musyawarah terlebih dahulu).

3. Zona pemanfaatan yaitu: (kawasan di mana ikan-ikan yang ada di kawasan ini bebas untuk dimanfaatkan atau diperbolehkan menangkap ikan dengan alat tangkap yang ramah lingkungan.

4. Zona lainnya yaitu: (kawasan di luar ke tiga kawasan diatas), karena fungsi dan kondisinya ditetapkan sebagai kawasan tertentu. Kawasan ini dapat berupa kawasan perlindungan dan kawasan rehabilitasi.

Tata kelola (sistem) yang telah dilakukan oleh masyarakat di lubuk larangan yaitu kebiasaan masyarakat yang bersifat adaptif, partisipasi, institusionalisasi (perilaku (individu), kelompok, norma dan sanksi) dan perubahan sosial (Dani et al. 2016) guna melestarikan sumberdaya perikanan perairan lotik (sungai) khususnya ikan endemik (lokal) (Oktaviani et al. 2016; ). Selain itu lubuk larangan adalah contoh model tata kelola perikanan berbasis masyarakat (Community Based Management/CBM) dengan teknik melakukan pengisolasian sementara waktu pada area penangkapan ikan di perairan lotik dan lentik (Suhana 2008; Kholis et al. 2018). Berdasarkan Parwati (2012) ada tiga elemen penting untuk mengelola lubuk larangan yaitu: kepercayaan (mitos), memberlakukan hukum adat dan kelembagaannya. Wujud tata kelola lubuk larangan melibatkan masyarakat dengan cara pengisolasian area dalam waktu tertentu. Adanya aturan dan memberi batas untuk penangkapan ikan di lubuk larangan meliputi: area diberi batasan dan tanda penjelas (zonasi); setiap lubuk memiliki wilayah terbatas; aturan adat istiadat berupa sangsi berupa (uang, harta benda/barang dan hukuman lainnya); larangan menangkap ikan dengan alat tangkap yang dilarang pemerintah; dilarang menangkap ikan pada musim pemijahan; dan mengatur periode panen (Dani et al. 2016).

Tradisi lubuk larangan di Kabupaten Bungo masih diterapkan sebagian kampung/dusun seperti di kecamatan yang ada di Kabupaten Bungo dan sekitarnya. Tercatat pada tahun 2018 ada 128 lubuk larangan di Kabupaten Bungo (Disnakkan Kabupaten Bungo 2018; Kholis et al. 2020). Dusun yang memiliki lubuk larangan umumnya memiliki perjanjian bersama (ikrar/sumpah) untuk menjaga lubuk dari pelanggaran illegal fishing. Apabila masyarakat ada yang melanggarnya maka akan diberi hukuman adat dan secara spiritual akan temakan ikrar/sumpahnya, sehingga ada yang sakit dan bahkan meninggal dunia (Susilowati 1999; Sairun et al. 2019; Kholis et al. 2020).

Eksistensi lubuk larangan ini dapat diwujudkan menjadi sebuah arah konservasi suatu perairan yang memiliki sumberdaya perikanan penting bagi masyarakat. Aturan pembentukan area konservasi sebagian telah diatur dalam PP No. 60 Tahun 2007 Tentang Konservasi Sumber Daya Ikan dan PERMEN KP RI Nomor PER.02/MEN/2009 Tentang Tata Cara Penetapan area Konservasi Perairan.

\section{Kearifan Lokal Lubuk Larangan Menuju SDGS'14}

\section{Kesehatan Perairan}

Komposit domain kesehatan perairan yaitu dilihat aspek fisika, kimia dan biologi. Pada penelitian ini aspek fisika dan kimia yang dilihat yaitu: arus, suhu, kecerahan, kedalaman, $\mathrm{pH}, \mathrm{DO}$ dan TSS, yang bertujuan untuk menggambarkan kondisi perairan tercemar atau tidak tercemar. Hasil pengamatan dan pengukuran lapang didapatkan aspek fisika dan kimia perairan lubuk larangan tepian napal yaitu: suhu perairan berkisar $27-28^{\circ} \mathrm{C}$, kecepatan arus $0,14 \mathrm{~m} / \mathrm{det}$, kecerahan $48,5 \mathrm{~cm}$, kedalaman 1-2,5 m, pH 5,78 ppm, DO 6,44 mg/l dan TSS 20,4 mg/l. Data lapang menunjukkan bahwa perairan lubuk larangan tepian napal terkategori tidak tercemar berdasarkan PP Nomor 82/2001 tentang Pengelolaan Kualitas Air dan Pengendalian Pencemaran Air Kelas III (Tabel 3).

Sedangkan aspek biologi pada penelitian ini yaitu melihat keanekaragaman jenis ikan tinggi, sedang atau rendah serta menghitung jumlah spesies yang ditemukan bervariatif atau tidak. Perairan 
dikatakan baik jika ikan masih banyak ditemukan dengan kemunculan spesies bervariatif dan indeks keanekaragaman tinggi. Hasil perhitungan didapatkan indeks keanekaragaman (' $\mathrm{H})$ lubuk larangan tepian napal sebesar 2,3, nilai $\mathrm{H}^{\prime}$ tersebut masih di bawah nilai kriteria domain kesehatan perairan $\mathrm{H}^{\prime}$ > 3. Hal itu dapat disebabkan pengaruh biologis ikan, lingkungan dan cuaca sehingga indeks keanekaragaman perairan masih tergolong sedang. Dalam artian bahwa telah terjadi degradasi perairan yang menyebabkan keanekaragaman kategori sedang. Syarat yang terpenuhi yaitu jenis ikan yang tertangkap saat panen melebihi 5 spesies yaitu 17 spesies. Menurut Kartamihardja et al. (2017) bahwa perairan lotik dan lentik di Indonesia mempunyai biodiversity species ikan yang tinggi, sehingga tercatat sebagai salah satu perairan dengan mega biodiversity di dunia.

Tabel 3 Kualitas perairan lubuk larangan tepian napal

\begin{tabular}{cccccl}
\hline No & Paremeter & Hasil Pengukuran & Satuan & $\begin{array}{c}\text { Standar Baku } \\
\text { Mutu }\end{array}$ & Keterangan \\
\hline & Fisika & $0,03-0,14$ & $\mathrm{~m} / \mathrm{det}$ & $<0,56$ & Sesuai \\
\hline 1 & Arus & $27-28$ & ${ }^{\circ} \mathrm{C}$ & $20-32$ & Sesuai \\
2 & Suhu & 48,5 & $\mathrm{~cm}$ & $>45$ & Sesuai \\
3 & Kecerahan & $1-2,5$ & $\mathrm{~m}$ & - & Proporsional \\
4 & Kedalaman & 6,44 & $\mathrm{mg} / 1$ & $3-6$ & Sesuai \\
5 & DO & & & & \\
\hline & Kimia & 5,78 & $\mathrm{ppm}$ & $6-9$ & Sesuai \\
\hline 1 & pH & 20,4 & $\mathrm{mg} / 1$ & $<50$ & Sesuai \\
\hline
\end{tabular}

Hasil analisis komposit domain kesehatan perairan, lubuk larangan tepian napal masuk kategori nilai atribut baik sekali (green flag) dengan skor 60. Lebih jelas analisis komposit domain kesehatan perairan dapat dilihat pada (Tabel 4).

Tabel 4 Analisis komposit domain kesehatan perairan

\begin{tabular}{lc}
\hline Kesehatan Perairan & Indikator \\
\hline Hasil & Tidak tercemar dan jumlah spesies $>5$ \\
Skor & 3 \\
Bobot & 20 \\
Nilai Atribut & 60 \\
\hline
\end{tabular}

\section{Proporsi Hasil Tangkapan}

Peningkatan hasil tangkapan setiap panen merupakan indikator keberhasilan suatu lubuk larangan yang telah dibuat masyarakat. Keberhasilan itu merupakan proses dan usaha masyarakat dalam mentaati aturan yang berlaku, sehingga lubuk larangan dapat terjaga dengan baik.

Atribut domain proporsi tangkapan ikan diartikan sebagai persentase pemanfaatan hasil tangkapan dalam tingkat daya produksi yang maksimal dan berkelanjutan. Parameter ini menggambarkan penilaian penting dari pengelolaan perikanan yang sustainability. Kategorisasi terhadap hasil tangkapan ikan yaitu: fully-exploited, over-exploited dan non-fully exploited (Badan Pusat Statistik 2014). Hasil tangkapan panen lubuk larangan di Kabupaten Bungo memiliki tren meningkat pada tiap tahunnya sekitar 30\% per tahun (Disnakkan Kabupaten Bungo 2018). Pada tahun 2018 lubuk larangan tepian napal panen ikan sebanyak $\pm 1000 \mathrm{~kg}$. Hasil analisis komposit domain proporsi hasil tangkapan ikan lubuk larangan tepian napal masuk kategori nilai atribut baik sekali (green flag) dengan skor 60 (Tabel 5). 
Tabel 5 Analisis komposit domain proporsi hasil tangkapan

\begin{tabular}{lc}
\hline Proporsi HT & Indikator \\
\hline Hasil & Hasil tangkapan atau panen stabil dan meningkat \\
Skor & 3 \\
Bobot & 20 \\
Nilai Atribut & 60 \\
\hline
\end{tabular}

\section{Illegal Fishing}

Komposit domain illegal fishing berfungsi mengetahui bagaimana penggunaan teknik penangkapan ikan yang destruktif seperti: potas, bom, setruman, senapan ikan dan alat tangkap lain yang berdampak terhadap sistem ekologi perairan lotik dan lentik. Selain itu komposit domain illegal fishing juga digunakan untuk melihat pelanggaran-pelanggaran lain yang bersifat adat maupun konstitusional negara di sekitar kawasan lubuk larangan. Pada analisis ini didapatkan bahwa frekuensi kasus pelanggaran di lubuk larangan tepian napal lebih kurang 5-10 kasus dalam per tahun, dan masuk kategori nilai atribut sedang (yellow flag) dengan skor 40 (Tabel 6). Kasus yang sering terjadi yaitu penggunaan alat tangkap ikan destruktif (potas dan setrum), penangkapan ikan tanpa izin, tidak membayar saat panen dan membuang sampah atau buang air kecil di kawasan lubuk larangan.

Tabel 6 Analisis komposit domain illegal fishing

\begin{tabular}{lc}
\hline Illegal fishing & Indikator \\
\hline Hasil & Frekuensi pelanggaran 5-10 kasus per tahun \\
skor & 2 \\
Bobot & 20 \\
Nilai Atribut & 40 \\
\hline
\end{tabular}

\section{Eutrofikasi}

Hasil analisis komposit eutrofikasi nilai atribut kategori sedang (yellow flag) dengan skor 40. Lebih jelas hasil analisis komposit domain eutrofikasi dapat dilihat pada (Tabel 7).

Tabel 7 Analisis komposit domain eutrofikasi

\begin{tabular}{lc}
\hline Eutrofikasi & Indikator \\
\hline Hasil & Masih ada aktivitas menangkap ikan, PETI, mandi, cuci dan kakus (MCK) \\
skor & 2 \\
Bobot & 20 \\
Nilai Atribut & 40 \\
\hline
\end{tabular}

Eutrofikasi dapat dijelaskan sebuah problem habitat yang disebabkan oleh limbah fosfat (PO3-), terutama dalam sistem ekologi air tawar, atau pencemaran air yang disebabkan oleh mencuatnya nutrien berlebih ke dalam sistem ekologi air (Badan Pusat Statistik 2014; Alfionita et al. 2019). Pada kajian ini eutrofikasi dilihat dari aspek kegiatan manusia (human activity), karena kegiatan manusia bisa membuat peningkatan limbah yang tidak diolah menjadi eutrofikasi, ekspansi alga berbahaya (HAB) dan "zona mati". Menurut Sentosa et al. (2018) adanya kegiatan manusia di sekitaran Danau Matano ditaksir dapat memberikan efek pada pencemaran organik, sehingga padatnya butiran hara yang masuk ke dalam badan danau yang berpotensi menyebabkan penyuburan tinggi pada perairan, sehingga butiran hara berubah menjadi racun (Murtiono dan Wuryanta 2016).

Oleh karena itu tingkat kegiatan manusia perlu kontrol dari pemerintah dan masyarakat. Berdasarkan Simbolon (2016) lajunya industry activity dan human activity di area di sepanjang pesisir wilayah Tangerang berpeluang terjadi pencemaran di daerahnya. Adanya bahan organik yang tanpa 
sengaja terbuai melalui limbah yang dihasilkan oleh industry activity dan human activity akan mengalir ke perairan dan saat kondisi tertentu akan mengganggu kualitas perairan.

Hasil pengamatan di lapang dan wawancara bahwa aktivitas manusia di sekitar lubuk larangan tepian napal masih banyak, terutama mandi, cuci dan kakus (MCK). Di samping itu ada juga aktivitas PETI (penambangan emas tanpa izin) yang menyebabkan air keruh dan merusak lingkungan. Hal seperti ini sangat perlu diawasi pemerintah, karena aturan yang telah dibuat tidak sepenuhnya dijalankan masyarakat tanpa pengawasan yang intensif.

\section{Tata Kelola (Kelembagaan)}

Lubuk larangan tepian napal dikelola secara sukarela dan partisipatif oleh masyarakat dusun Tanah Tumbuh. Lubuk larangan ini memiliki badan hukum yaitu peraturan dusun yang disahkan RIO (Kepala Desa). Selain itu ada juga pengawasan dari POKMASWAS (Kelompok Masyarakat Pengawas) yang ditugaskan RIO untuk mengawasi lubuk larangan selama 2 tahun atau sampai waktu panen. Aturan dan sanksi yang diberlakukan di lubuk larangan tepian napal dapat dilihat (Tabel 8).

Tabel 8 Aturan dan sanksi lubuk larangan tepian napal

\begin{tabular}{cccl}
\hline No & \multicolumn{1}{c}{ Aturan } & \multicolumn{1}{c}{ Sanksi } \\
\hline 1 & Barang siapa terbukti dengan sah dan benar & Rp.10.000.000,- (Sepuluh Juta \\
melakukan penangkapan ikan secara illegal & Rupiah) atau hutang adat duo puluh \\
dengan alat dan cara apapun di dalam kawasan & penuh atau satu ekor kambing. \\
& lubuk larangan akan didenda dan terkena & \\
& hukuman adat. & \\
2 & Apabila pelaku melakukan penangkapan ikan & Pidana penggunaan alat tangkap \\
& tersebut di dalam kawasan lubuk larangan atau & ikan yang dilarang beropeasi atau \\
& sekitarnya dengan menggunakan alat tangkap & merusak lingkungan sesuai \\
& destruktif maka akan dikenakan sanksi pidana. & PERMEN KP No. 02/2015. \\
3 & Apabila pelaku penangkapan ikan di kawasan & Pidana tindak pencurian sesuai \\
& lubuk larangan tidak mau mentaati hukuman & PERDUS No.01/2016 tentang tata \\
& denda adat, maka pemerintah dusun akan & cara pengelolaan lubuk larangan \\
& melaporkan ke pihak berwajib (Kepolisian RI) & dalam wilayah dusun Tanah \\
& dengan aduan tindak pidana pencurian. & Tumbuh. & \\
\hline
\end{tabular}

Peran kelembagaan sangat penting dalam sistem atau tata kelola perikanan berkelanjutan. Menurut Purwaka (2003) kinerja dari suatu kelembagaan adalah kegunaan dari susunan tata kelembagaan (institutional arrangement), kapasitas kelembagaan (institutional capacity) dan sistem kelembagaan (institutional framework). Kinerja suatu kelembagaan dapat dinilai melalui beberapa indikator seperti: pendekatan aspek sosial budaya, politik, hukum, ekonomi dan teknologi.

Kelembagaan yang terlibat dalam pengelolaan lubuk larangan ini yaitu: Pemerintah Daerah (Bupati), Badan Permusyawarah Dusun (BPD), Pemerintah Dusun (RIO), Pemerintah Kecamatan (Camat), Lembaga Pemberdaya Masyarakat (LPM), Badan Usaha Milik Dusun (BUMD), Dewan Kemakmuran Masjid (DKM), Rukun Tetangga (RT), Rukun Warga (RW), Pemuda Talang Taruna (PTT) dan Organisasi eksternal lainnya.

Salah satu peran kelembagaan tata kelola lubuk larangan tepian napal yaitu membuat batasan konstitusional agar masyarakat mengetahui mana wilayah pengelolaan lubuk larangan. Pemberian batas lubuk larangan tepian napal dilakukan dengan cara melintangkan tali di atas sungai pada bagian hilir atau hulunya sebagai pembatas pada kawasan lubuk larangan. Ditambahkan Sairun et al. (2019) wilayah lubuk larangan dicirikan oleh perbedaan kecepatan aliran air sungai (lubuk larangan biasanya memiliki arus tenang), dan bisa juga menggunakan pelampung besar di atas air atau tali yang direntangkan di atas air. 
Pemerintah dusun juga baiknya menentukan lokasi/wilayah lubuk larangan dengan titik koordinat menggunakan GPS agar keakuratan data dan posisi lebih efektif dan teraktualisasi. Hasil analisis komposit domain tata kelola (kelembagaan) didapatkan nilai atribut baik sekali (green flag) dengan skor 60 (Tabel 9).

Tabel 9 Komposit atribut domain tata kelola (kelembagaan)

\begin{tabular}{lc}
\hline Tata kelola (Kelembagaan) & Indikator \\
\hline Hasil & Perairan tertutup dan dilindungi \\
Skor & 3 \\
Bobot & 20 \\
Nilai Atribut & 60 \\
\hline
\end{tabular}

\section{Implementasi SDGs'14 Berkelanjutan}

Inland waters (perairan lotik dan lentik) adalah perairan yang begitu melekat historinya bagi kehidupan manusia pada umumnya. Peran penting perairan umum dan daratan sebagai penopang ekosistem yang akan bermuara ke lautan. Pencemaran dilaut salah satu indikatornya berasal dari perairan lotik dan lentik. Implementasi SDGs'14 sangat berdampak bagi pengelolaan berkelanjutan di inland waters. Proses implementasi tentu perlu tahapan dan proses yang panjang sehingga mampu mewujudkannya.

Inland waters di Indonesia mempunyai luas berkisar 13,85 juta ha, diantaranya 12 juta ha perairan yang mengalir (sungai) dan paparan banjiran (flood plains), 0.05 juta ha danau buatan (man made lakes) atau waduk (reservoirs) dan 1,8 juta ha danau alam (natural lakes) (Kartamihardja et al. 2017). Inland waters merupakan seluruh fisik air yang tercipta secara natural atau non natural (buatan) dan memiliki pengaruh dari garis pasang surut terendah sampai arah daratan yang tidak ada kepemilikan. Dengan demikian, inland waters meliputi: danau, waduk, rawa, sungai dan paparan banjir serta genangan air lainnya. Berdasarkan (Tabel 10) dapat dilihat hasil analisis rekapitulasi antar komposit pada setiap domain didapatkan bahwa domain kesehatan perairan, proporsi hasil tangkapan dan tata kelola (kelembagaan) memiliki nilai atribut baik sekali (green flag) dengan skor 60. Domain illegal fishing dan eutrofikasi memiliki nilai atribut sedang (yellow flag) dengan skor 40. Hasil rata-rata atau agregat kelima domain yang dianalisis didapatkan nilai atribut baik (light green flag) dengan skor 52.

Tabel 10 Rekapitulasi hasil analisis komposit pada setiap domain

\begin{tabular}{lcll}
\hline \multicolumn{1}{c}{ Domain } & $\begin{array}{c}\text { Nilai } \\
\text { Atribut }\end{array}$ & Bendera & Keterangan \\
\hline Kesehatan Perairan & 60 & Baik Sekali \\
Proporsi Hasil Tangkapan & 60 & Baik Sekali \\
Illegal Fishing & 40 & Sedang \\
Eutrofikasi & 40 & Sedang \\
Tata kelola (Kelembagaan) & 60 & Baik Sekali \\
Rata-rata/Agregat & 52 & Baik \\
\hline
\end{tabular}

Lubuk larangan tepian napal memiliki domain dari nilai atribut yang masih dianggap kurang pengaruhnya dalam pelaksanaan sustainable development goals (SDGs'14). Hal itu dapat dilihat dari (Gambar 3) bagaimana profil penilaian belum semuanya merata, namun hal ini masih bersifat evaluasi dan masih bisa ditingkatkan statusnya untuk mengarah menuju SDG'14. Upaya tindak lanjutnya dapat berupa perbaikan status nilai atribut dalam implementasi program SDGs'14 nantinya. 


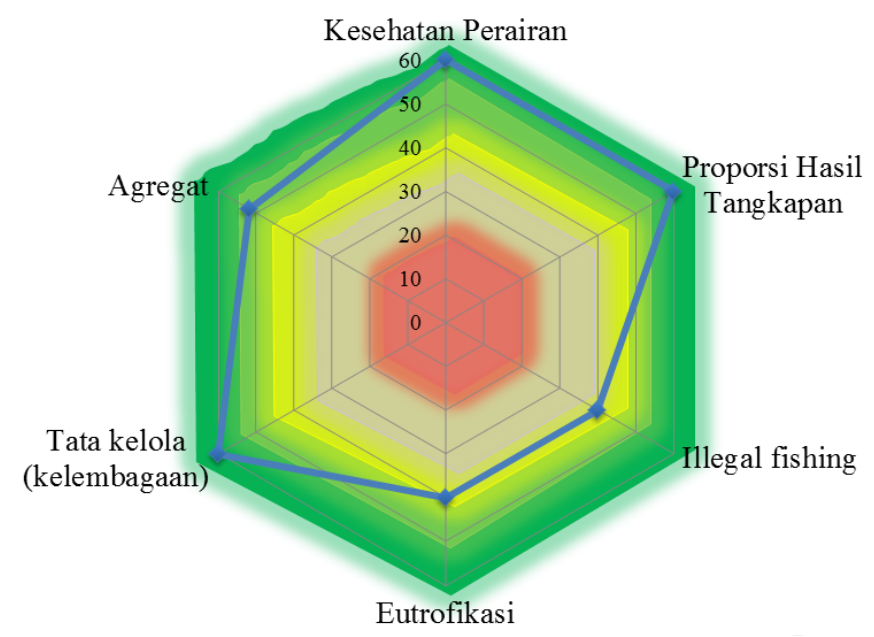

Gambar 3 Profil domain dari atribut SDG'14 lubuk larangan tepian napal

Salah satu alat sebagai pengelolaan perikanan perairan lotik dan lentik secara berkelanjutan yaitu dengan adanya kearifan lokal lubuk larangan. Selain menjaga ekosistem di perairan, lubuk larangan juga berperan untuk memberikan pendapatan bagi masyarakat. Menurut Firdaus dan Huda (2015) eksistensi lubuk ini telah mempersembahkan kekuatan sebagai wujud pelestarian sumberdaya ikan dan meningkatkan pendapatan warga di sekitar lubuk dengan cara membuat kedai untuk menjual drink water dan snack bagi para pengunjung lubuk larangan. Berdasarkan Firdaus dan Sari (2017) manfaat ekstraktif adanya lubuk larangan di lubuk panjang Sumatera Barat yaitu aktivitas pariwisata yang memperoleh hasil surplus sebanyak 3,95 milyar rupiah per tahun. Anggaran mengelola lubuk larangan tersebut terdapat biaya investasi sebesar Rp. 97.201.300,- dan biaya operasional sebesar Rp. 12.650.000,- per tahun.

Kearifan lokal lubuk larangan dapat berperan jika melibatkan seluruh pihak, terutama pihak paguyuban warga lokal yang bermukim di sekitar lubuk tersebut. Menurut Nikijuluw (2002); Kartamihardja et al. 2014; Oktaviani et al. 2016) manajemen/tata kelola perikanan yang memanfaatkan masyarakat sebagai basisnya (Community Based Fisheries Management/CBFM) sangat tepat digunakan masyarakat di Indonesia, karena memberi kewenangan, tanggung jawab dan memberi peluang kepada masyarakat untuk mengelola sumberdaya perikanan di areanya sendiri. Selain itu menurut Hidayah et al. (2016) rasa sadar masyarakat terhadap lingkungan merupakan point penting dalam mengelola sumberdaya perairan, karena rasa sadar terhadap lingkungan merupakan wujud kepedulian masyarakat terhadap kualitas hidup, sehingga timbul partisipasi masyarakat untuk melawan/protes kebijaksanaan yang tidak berwawasan lingkungan.

Pemanfaatan sumberdaya perikanan ini memiliki potensi pergesekan konflik horizontal tinggi, yang faktor penyebabnya berupa ketidakadilan dalam mengeksploitasi sumberdaya baik itu karena ketidakadilan penggunaan teknologi, maupun ketidakadilan dalam memperoleh peluang untuk memanfaatkan potensi sumberdaya tersebut. Menurut Mari (2018) bantuan subsidi sudah terlalu banyak untuk nelayan kecil (small fisheries), sehingga terjadi penangkapan ikan berlebihan di lautan, dan sekarang mengancam pendapatan mereka. Pemerintah harus memilih kebijakan sesuai kebutuhan perikanan masa kini, sehingga tidak adanya lagi kesenjangan sosial.

Usaha pemerintah dalam menjamin keberlangsungan pengelolaan sumberdaya perairan lotik dan lentik yaitu dengan menetapkan PERMEN KP No.09/2020 tentang wilayah pengelolaan perikanan negara Republik Indonesia di perairan darat (WPPRI PD). Hal itu diharapkan mampu mengatasi permasalahan over exploitasi, pencemaran lingkungan, penebaran ikan native species dan kisruh sosial yang ada di perairan umum dan daratan. Oleh karena itu dibutuhkan sinergi antara pemerintah, kelembagaan dan masyarakat yang harus dijaga dengan baik, agar terciptanya hubungan keharmonisan demi mewujudkan perikanan yang berkeadilan dan berkelanjutan. 
Menurut Adrianto (2005) perikanan memiliki konstribusi penting dalam pengadaan kesempatan kerja, rekreasi, perdagangan, bahan pangan dan kemakmuran ekonomi. Lubuk larangan tepian napal dapat dikatakan sudah baik untuk menerapkan program SDGs'14 sebagai life below water, dengan upaya melestarikan dan menjaga keberlangsungan ekosistem serta kehidupan sumber daya perairan umum dan daratan. Diharapkan nantinya lubuk larangan mampu berkonstribusi memberikan dampak positif kepada perkembangan pembangunan perikanan nasional.

Konsep utama SDGs'14 yaitu menangani perlindungan wilayah, konservasi dan manajemen ekosistem sumberdaya perairan. Pada tahun 2030 target SDGs adalah mengadopsi apa yang disebut "model tiga pilar" menyeimbangkan ekonomi, sosial, dan dimensi lingkungan (Neuman et al. 2017). Langkah selanjutnya, tidak kalah penting yaitu mensinergikan antara SDGs'14 dengan ke-enam belas tujuan penting lainnya dalam Sustainable Development Goals (SDGs).

\section{KESIMPULAN DAN SARAN}

Penelitian ini dapat disimpulkan bahwa kearifan lokal lubuk larangan tepian napal sudah mengarah ke SDGs'14 dengan kategori baik (light green flag). Sistem partisipatif, adat-istiadat dan kekeluargaan menjadi ciri khas kearifan lokal lubuk larangan dalam menjaga sumberdaya perikanan di Kabupaten Bungo Provinsi Jambi. Kedepannya diperlukan pengawasan dan kontrol yang baik dari Pemerintah Daerah dan Pemerintah Dusun dari terjadinya illegal fishing dan eutrofikasi. Kedua domain tersebut perlu ditingkatkan statusnya untuk mencapai tujuan SDGs'14.

\section{UCAPAN TERIMA KASIH}

Kami sampaikan ucapan terima kasih kepada RIO (Kepala Desa) Tanah Tumbuh dan masyarakat Dusun Tanah Tumbuh yang telah banyak membantu dalam pengambilan data pada penelitian ini.

\section{DAFTAR PUSTAKA}

Adrianto, L. 2005. Valuasi Ekonomi Sumberdaya Pulau-Pulau Kecil. Paper disampaikan pada Sosialisasi Pedoman Investasi Pulau-Pulau Kecil. Direktorat Jenderal Pesisir dan Pulau-Pulau Kecil, Departemen Kelautan dan Perikanan. Mataram, 28.

Adrianto, L., Matsuda, T., \& Sakuma, Y. 2005. Assessing sustainability of fisheries systems in a small island region; Flag modeling approach. Proceedings of IIFET. Tokyo (JP).

Alfionita, A. N. A., Patang, P., \& Kaseng, E. S. 2019. Pengaruh Eutrofikasi Terhadap Kualitas Air di Sungai Jeneberang. Jurnal Pendidikan Teknologi Pertanian, 5(1), 9-23.

Badan Pusat Statistik. 2014. Kajian Indikator Sustainable Development Goals (SDGs). Jakarta: Badan Pusat Statistik.

Dani, A. P., Nugroho, F., \& Amrifo, V. 2016. Kearifan Lokal Lubuk Larangan Sebagai Upaya Pelastarian Sumberdaya Perairan di Nagari Sikucur Kecamatan V Koto Kampung Dalam Kabupaten Padang Pariaman Provinsi Sumatera Barat. Berkala Perikanan Terubuk, 44(2), 89-99.

Dinas Peternakan dan Perikanan (Disnakkan) Kabupaten Bungo. 2018. Laporan Statistik Perikanan Kabupaten Bungo, Jambi.

Edwarsyah, Yonvitner, dan Muhtadi, A. 2018. Pengantar Pengelolaan Perikanan Berbasis Ekosistem/EAFM: Teori dan Praktik Edisi Revisi. (166 p). Bogor: IPB Press.

Firdaus, M., \& Huda, H. M. 2015. Pengelolaan Sumberdaya Ikan di Sungai (Studi Kasus: di Kabupaten Pesisir Selatan, Provinsi Sumatera Barat). Buletin Ilmiah Marina Sosial Ekonomi Kelautan dan Perikanan, 1(1), 41-47. 
Firdaus, M., \& Sari, Y. D. 2017. Pemanfaatan dan Pengelolaan Kawasan Konversi Sumberdaya Perikanan (Studi Kasus di Lubuk Panjang-Barung Balantai, Kabupaten Pesisir Selatan, Sumatera Barat. Jurnal Sosial Ekonomi Kelautan dan Perikanan, 5(1), 1-18.

Handayani, M., Djunaidi, D., \& Hertati, R. 2018. Sistem Pengelolaan Lubuk Larangan Sebagai Bentuk Kearifan Lokal di Sungai Batang Tebo Kabupaten Bungo Provinsi Jambi. SEMAH Jurnal Pengelolaan Sumberdaya Perairan, 2(3), 1-8.

Hidayah, N., Syarifuddin, S., \& Gultom, T. 2016. Analisis Pengetahuan Lingkungan dan Sikap Peduli Lingkungan terhadap Ekosistem Sungai Berbasis Kearifan Lokal Lubuk Larangan di Desa Tambangan Jae Kecamatan Tambangan Kabupaten Madina. Jurnal Pendidikan Biologi, 5(2), 108-112.

Indrawan, M., Primack, R. B \& Supriatna, J. 2007. Biologi konervasi. Edisi Revisi (p xviii, 626).Yayasan Obor Indonesia, Jakarta.

Ishatono, I., \& Raharjo, S. T. 2016. Sustainable development goals (SDGs) dan pengentasan kemiskinan. SHARE: Social Work Journal, 6(2), 159.

Kartamihardja, E. S., \& Umar, C. dan Aisyah. 2014. Pembelajaran dari pengelolaan dan Konservasi Sumber Daya Ikan Arwana Merah (Scleropages formosus, Muller and Schlegel, 1844) Bebasis Masyarakat di Danau Empangau, Kalimantan Barat. J. Kebijak. Perikan. Ind, 6(2), 55-64.

Kartamihardja, E. S., Purnomo, K., \& Umar, C. 2017. Sumber Daya Ikan Perairan Umum Daratan di Indonesia-Terabaikan. Jurnal Kebijakan Perikanan Indonesia, 1(1), 1-15.

Keraf, A. S. 2002. Etika lingkungan. Penerbit Buku Kompas.

Kholis, M. N., Amrullah, M. Y., Martasuganda, S., \& Saputra, F. 2020. Studi Rancang Bangun Kontruksi Rumpon Lubuk Larangan di Kabupaten Bungo Provinsi Jambi. PELAGICUS, 1(2), 71-81.

Kholis, M. N., Wahju, R. I., \& Mustaruddin, M. 2018. Prioritas Pengelolaan Usaha Penangkapan Ikan Kurau di Pambang Pesisir Kabupaten Bengkalis Provinsi Riau. SEMAH Jurnal Pengelolaan Sumberdaya Perairan, 2(3), 1-16.

Kurniasari, N., Yulisti, M., \& Yuliaty, C. 2015. Lubuk larangan: Bentuk perilaku ekologis masyarakat lokal dalam pengelolaan sumber daya perikanan perairan umum daratan (tipologi sungai). Jurnal Sosial Ekonomi Kelautan dan Perikanan, 8(2), 241-249.

Mari, F. J. 2018. SDG 14. Sustainable fishery or Blue Economy?, Civil Society Reflection Group on the 2030 Agenda for Sustainable Development Exploring new policy pathways. Page 150.

Munandar, R. A., Sarong, M. A., \& Edwarsyah, E. 2018. Pengelolaan Perikanan Lobster (Panulirus Sp.) Dengan Metode Ecosystem Approach to Fisheries Management Di Kabupaten Simeulue. Jurnal Perikanan Tropis, 5(1), 1-12.

Murtiono, U. H., \& Wuryanta, A. 2016. Telaah Eutrofikasi pada Waduk Alam Rawapening.

Neumann, B., Ott, K., \& Kenchington, R. 2017. Strong sustainability in coastal areas: a conceptual interpretation of SDG 14. Sustainability science, 12(6), 1019-1035.

Nikijuluw, V. P. (2002). Rezim pengelolaan sumberdaya perikanan. Kerja sama Pusat Pemberdayaan dan Pembangunan Regional (P3R) dengan PT. Pustaka Cidesindo.

Oktaviani, D., Prianto, E., \& Puspasari, R. 2016. Penguatan kearifan lokal sebagai landasan pengelolaan perikanan perairan umum daratan di Sumatera. Jurnal Kebijakan Perikanan Indonesia, 8(1), 112.

Parwati, A. 2012. Nilai Pelestarian Lingkungan dalam Kearifan Lokal Lubuk Larangan Ngalau Agung. In Prosiding Seminar Nasional Pengelolaan Sumberdaya Alam dan Lingkungan (pp. 98-103). 
Purwaka, T. H. 2003. Bunga Rampai Analisis Pengembangan Kapasitas Kelembagaan Kelautan dan Perikanan. Jakarta: THP.

Rengi, P., Brown, A. 2013. Studi Konservasi Ikan Kurau di Selat Malaka Provinsi Riau. (Pekanbaru, Seminar Nasional Konservasi dan Proteksi Lingkungan. 27 hlm.

Sairun, S., Syafrialdi, S., \& Djunaidi, D. 2019. Pengelolaan Lubuk Larangan Sebagai Bentuk Kearifan Lokal di Sungai Batang Jujuhan Kabupaten Bungo Provinsi Jambi. SEMAH Jurnal Pengelolaan Sumberdaya Perairan, 3(1), 1-11.

Sentosa, A. A., Hedianto, D. A., \& Satria, H. 2018. Dugaan Eutrofikasi di Danau Matano Ditinjau dari Komunitas Fitoplankton dan Kualitas Perairan. LIMNOTEK-Perairan Darat Tropis di Indonesia, 24(2), 61-73.

Simbolon, A. R. 2016. Pencemaran Bahan Organik Dan Eutrofikasi Di Perairan Cituis, Pesisir Tangerang. Pro-Life, 3(2), 109-118.

Suhana. 2008. Pengakuan Keberadaan Kearifan Lokal Lubuk Larangan Indarung, Kabupaten Kuantan SingingiProvinsiRiauDalamPengelolaan dan Perlindungan Lingkungan Hidup (p.7). Pusat Kajian Pembangunan Kelautan dan Peradaban Maritim (PK2PM).

Susilowati, I. 1999. An Analysis of Co-Management Fisheries in West Sumatra Province, Indonesia: A Case Study of Ikan Larangan. In International Workshop on Fisheries Co-management, Penang, Malaysia (pp. 23-29).

Yuliaty, C., \& Priyatna, F. N. 2014. Lubuk Larangan: Dinamika Pengetahuan Lokal Masyarakat Dalam Pengelolaan Sumber Daya Perikanan Perairan Sungai di Kabupaten Lima Puluh Kota. Jurnal Sosial Ekonomi Kelautan dan Perikanan, 9(1), 115-125. 